\title{
Sosiale kruisigingsteks(te) van 110 Tempel 64.6-13: 'n Ondersoek na intertekstualiteit
}

\author{
Ananda Geyser \& Andries van Aarde \\ Departement Nuwe-Testamentiese Wetenskap (Afd A) \\ Universiteit van Pretoria
}

\begin{abstract}
Social crucifixion text(s) of $11 \mathrm{Q}$ Temple 64.6-13: An investigation into intertextuality

This article asks certain questions about the assumption that Israelites did not use crucifixion as a penalty. It more specifically looks at the post-exilic era to $100 \mathrm{CE}$ and focuses on two crucifixion texts from the Dead Sea Scrolls (11Q 64.6-13 and 4 QpNahum) by means of the method of intertextuality. In other words, it compares the Qumran texts with the crucifying habits and traditions of neighbouring cultures. These habits and traditions are called the social text(s). This article assumes that a text is not only a written but also a happened text. In other words, context is also taken to be a text.
\end{abstract}

\section{INLEIDING}

Geleerdes hou hulle steeds besig met die vraag na wie werklik verantwoordelik was vir die kruisiging van Jesus Christus (kyk o a Crossan 1995). Ten spyte van getuienis in die kanonieke evangelies ${ }^{1}$, asook in ander buite-Bybelse bronne (GPt 1:1-2; 7:1, 8), handhaaf sekere navorsers die standpunt dat die praktyk van kruisiging nie deur Israeliete gebruik is om iemand tereg te stel nie (kyk o a Rosenblatt 1956). Die eksponente van hierdie standpunt gebruik die argument dat dit volgens Deuteronomium ${ }^{2}$ 'n skande was vir Israeliete om iemand te kruisig en dat dit 'n Romeinse straf was. Daar is egter ook ander geleerdes wat die blaam vir Christus se kruisiging op die skouers van die Jode lê (kyk o a Betz 1988).

\footnotetext{
* Hierdie artikel is ' $n$ verwerking van die resultate van die BD-skripsie, ingedien en aanvaar as deel van die vereistes vir die BD-graad (1996), Departement Nuwe-Testamentiese Wetenskap, Fakulteit Teologie (Afd A), Universiteit van Pretoria, onder leiding van prof dr A G van Aarde.
} 
In hierdie studie word daar nie 'n ondersoek gedoen na wie Christus se vervolgers in werklikheid was nie. Daar word wel van die aanname uitgegaan dat Israeliete waarskynlik ook mense gekruisig het. In hierdie ondersoek word daar veral gebruik gemaak van getuienis oor kruisigings wat plaasgevind het in die omliggende gebiede van Israel. Die tydperk waarna gekyk word, is die periode van ongeveer naballingskap tot ongeveer $100 \mathrm{n} \mathrm{C}$. Hierdie getuienis word die sosiale teks genoem. Die Quamranteks (11 QTempel 64.6-13) ${ }^{3}$ asook Deuteronomium 21:22-23, sal saam met die sosiale teks bestudeer word.

Voordat die spesifieke vraagstelling(s) van hierdie studie geformuleer word, is dit nodig om eers na terme soos 'intertekstualiteit' en 'teks(te)' te kyk asook na die manier waarop dit in die studie verstaan en gebruik word. Die term 'intertekstualiteit' is deur die Franse semiotikus, Julia Kristeva, onder die aandag van literatuurteoretici gebring, deurdat sy die werk van die Russiese taalfilo-soof, Mikhail Bakhtin, aan die Weste bekend gestel het. Bakhtin gebruik die term 'dia-logisme' om die bestaan van die tradisionele monologistiese 'woord'-opvatting te ontken. Elke woord en elke uiting is reaksie sowel as antisipasie op 'n woord of uiting van iemand anders (Van Gorp 1990). Viljoen (1993:314) formuleer dit soos volg: 'Elke diskoers is ook in dialoog met voorafgaande diskoerse oor dieselfde onderwerp, sowel as diskoerse wat nog moet kom en waarop dit in antisipasie gerig is.' Gräbe (1996:3) beskryf hierdie verskynsel van 'intertekstualiteit' soos volg:

\begin{abstract}
Die tekstuele ruimte waarbinne die 'literêre woord' funksioneer is definieerbaar in terme van sowel 'n horisontale (skrywende subjek-aangesprokene) as 'n vertikale (teks-konteks) as, met die gevolg dat elke woord (of teks) 'n kruispunt van woorde (tekste) verteenwoordig waar ten minste een ander woord (of teks) gelees kan word. Die implikasie van so 'n siening is dat skryf, vir Bakhtin, neerkom op 'n lees van 'n voorafgaande literêre korpus en dat die teks daarom gesien kan word as die absorbering van en antwoord op ' $n$ ander teks. Kristeva beklemtoon die feit dat Bakhtin die eerste is om hierdie belangrike insig in literêre teorie in te voer en dit is dan hierdie insig van die teks as ' $n$ kruispunt van ander tekste wat haar term intertekstualiteit inspireer.
\end{abstract}

Kristeva keer die imitatio-gedagte om, sodat tekste nie klakkeloos die tradisie reproduseer nie, maar eerder 'n kritiese lesing daarvan verteenwoordig (Claes 1987:9): '... any text is constructed as a mosaic of quotations; any text is the absorption and transformation of another. The notion of intertexuality replaces that of intersubjectivity and poetic language is read as at least double' (Kristeva 1980:66). 
Kristeva fokus ook op die funksieverandering wat 'n uiting uit 'n bepaalde teks in 'n nuwe teks ondergaan' en lê klem daarop dat hierdie veranderings sosiaal gedetermineerd is.

De term intertextualiteit wordt verder in de semiotiek in een ruimere betekenis gehanteerd. Men bedoelt er dan mee dat al wat ons omgeeft als 'tekst' kan worden beschouwd, b.v. de cultuur, de politiek enz. De talige tekst, i.c. het literaire werk, wordt dan gesitueerd tegenover deze 'teksten'. Het tekstgebeuren wordt beschouwd als een weefproces (Lat. textus $=$ weefsel) waarbij elke betekenis in andere betekenissen ingeweven wordt. De tekst is een betekenisknoop die naar verschillende culturele codes verwijst. Het geheel van codes dat de cultuur uitmaakt is op een gelijkaardige manier ineengestrengeld tot een textuur. Literaire, muzikale, politieke, wetenschappelijke en picturale teksten vormen alzo het weefsel dat het 'Boek der Cultuur' is.

(Van Gorp 1990:196)

Intertekstualiteit behels dus die ooreenkoms tussen tekste asook die invloed wat 'n vroeë teks uitoefen op 'n latere. Die term 'teks' word hier gesien as meer as net die literêre teks; daarom word daar in die titel van die onderhawige studie melding gemaak van 'sosiale kruisigingstekste'. 'Teks' behels nie net die geskrewe teks nie, maar ook die gebeurde teks; met ander woorde die gewoontes, gebruike en optredes van die tyd. Teks is dus ook konteks. Claes (1987:9) verwys soos volg na geleerdes wat hierdie selfde oortuiging het: 'Kristeva, Sollers en Barthes hebben de gehele cultuur beschreven als een tekst, zodat de intertextualiteit kan worden opgevat als het spel van interteracties daartussen'. Wanneer daar dan in die studie van die 'sosiale kruisigingstekste' gepraat word, veronderstel dit die gebeurde teks(te) van die Israeliete, sowel as van die omringende volke, met betrekking tot die kruisigingspraktyk.

In die lig van bogenoemde in verband met teks en interteks kan daar voortgegaan word deur twee vrae te vra: Eerstens, is die sosiale kruisigingsteks(te) die interteks vir 11 QTempel 64.6-13? Met ander woorde het die Esseense gemeenskap die kruisigingspraktyk op ' $n$ bepaalde wyse toegepas omdat hulle beïnvloed is deur omringende gebruike? Tweedens, was dit net die Qumran-gemeenskap wat deur die sosiale teks beïnvloed kon word? Met ander woorde, bestaan daar nie 'n moontlikheid dat ander Israelitiese gemeenskappe ook onder dié groepsdruk kon toegee nie? 


\section{KRUISIGING}

Die corsprong van kruisiging as ' $n$ vorm van teregstelling word normaalweg teruggevoer na die Perse. Hierdie standpunt kan aanvaar word, aangesien daar 'n hele aantal verwysings na kruisiging onder die Perse in Herodotes gevind word, onder andere die verwysing na Darius wat drie duisend inwoners van Babilonië gekruisig het (vgl Hengel $1977: 22$; Herodotes $1.128 ; 3.125,3 ; 3.132,2 ; 3.159,1)$. Hierdie gebeure word later bevestig deur Ctesias (vgl Hengel 1977; FGH 688 F 14.39; F 14.45; F16.66). Tog was kruisiging volgens antieke bronne die teregstellingsvorm van barbare (vgl Hengel 1977 m b t Justus Lipsius) soos die Indiane, Assiriërs, Skitiërs en die Tauriane. Dit is selfs gebruik deur die Kelte wat volgens Posidonius (vgl Hengel 1977:22) die kriminele aan hulle gode geoffer het. Later het ook die Numediane (inwoners van 'n landstreek in antieke Noord-Afrika in vandag se Algerië) en veral die Kartagiërs dit gebruik. Moontlik het die Romeine hierdie gebruik by hulle oorgeneem. Kruisiging was ook nie oorspronklik 'n Griekse vorm van straf nie, maar dit is wel later deur hulle uitgevoer. Kruisiging was hoofsaaklik 'n politieke en militêre straf. Die Perse en Kartagiërs het hoofsaaklik rebelse hoë offisiere en regeerders gekruisig, terwyl die Romeine dit gebruik het om die laer klas tereg te stel.

Soos reeds gesê, is kruisiging gesien as die mees barbaarse vorm van teregstelling. Almal het dit beskou as baie wreed en banaal, asook as 'n uiters vernederende vorm van straf. Ford (1995) sê dat kruisiging die volgende doel gehad het: (1) dit het die maksimum fisiese pyn veroorsaak; (2) dit was 'n besondere skandalige gebeurtenis; (3) dit is soms gebruik as ' $n$ offer vir gode en godinne, en (4) dit is ook gebruik om die slagoffer se gees te verhinder om sy/haar vervolgers te pla, deurdat die liggaam deur roofvoës en ander wilde diere opgevreet is.

Die antieke skrywers tref nie altyd onderskeid tussen wanneer iemand lewendig gekruisig is, of wanneer ' $n$ lyk opgehang is vir vertoon nie. In beide gevalle is dit egter gesien as blootstelling aan die ergste vorm van vernedering. Daar was ook geen vaste voorskrifte oor hoe kruisiging toegepas moes word nie (vgl Van der Watt \& Joubert 1996). Dit blyk duidelik uit Seneca (Dialogi 6) se getuienis: Video istic cruces, non unius quidem generis, sed aliter ab aliis fabricatas: capite quidam conuersos in terram suspendere, alii per obscena stipitem egerunt, alii brachia patibulo explicuerunt 4 (vgl Hengel 1977:25).

Die idee mag bestaan dat vroue, aangesien hulle nie dieselfde regte as mans gehad het nie, nie gekruisig is nie. Dit was egter nie die geval nie. Kruisiging is ook uitgevoer op vroue (kyk Ford 1995). Al het hulle nie dieselfde regte as mans gehad nie, is hulle met ander woorde aan dieselfde straf onderwerp. 


\section{KRUISIGING ONDER DIE ROMEINE}

Verwysings na kruisiging deur Latynse skrywers is relatief skaars. Skrywers soos Lucretius, Virgilius, Statius en Aulus Gellius wou klaarblyklik nie daaroor skryf nie, omdat dit te wreed en barbaars is. Ander skrywers soos Valerius, Maximus, Petronius en Apuleius was nie so fyngevoelig nie. Hengel (1977:38) is van mening dat die feit dat daar nie so baie verwysings na knuisiging in die antieke geskrifte voorkom nie, nie soseer 'n historiese probleem, as 'n estetiese was nie. Hy sê dat die gebruik wydverspreid en gereeld voorgekom het, veral in die Romeinse tyd, maar die gekultiveerde letterkundiges wou daar niks mee te doen hê nie. Die Joodse geskiedskrywer, Flavius Josephus, skryf in sy Bellum Judaicum dat Alexandra Salome, onder leiding van die Fariseërs, vir Diogenes laat dood maak het; hy is daarvan beskuldig dat hy die koning (Alexander Jannaeus) aangeraai het om sy agt honderd slagoffers te kruisig (kyk Neusner 1987; BJ I, 107-114).

Hengel (1977:39) sê dat daar gewoonlik aangeneem word dat Romeinse burgers nie gekruisig is nie. Dit is egter slegs gedeeltelik waar, aangesien daar wel 'n antieke straf was wat selfs op Romeine in geval van hoogverraad toegepas kon word. Die straf het behels dat mense aan 'n boom opgehang word. Hy wys egter ook daarop dat die straf bittermin toegepas is. Voorbeelde daarvan is onder andere die keer toe Scipio die drosters laat kruisig het (Hengel 1977:39 ; Valerius Maximus 2.7,12) en Verres wat $\mathbf{P}$ Gavius, wat 'n spioen was, gekruisig het (Hengel 1977; Cicero, In Verrem). Daar is selfs ' $n$ voorbeeld van ' $n$ persoon uit die Romeinse adelstand, ' $n$ senator, $C$ Rabirius, wat skuldig bevind is aan hoogverraad. Hy is in $63 \mathrm{v} \mathrm{C}$ deur Caesar veroordeel en tereggestel (Hengel 1977:41).

Alhoewel daar ' $n$ paar sulke voorbeelde is, is kruisiging in die Romeinse samelewing hoofsaaklik gesien as 'n straf vir slawe en vir die lae klas. Hengel sê ook dat Cicero 'n duidelike onderskeid tref tussen carnifex, obductio capitis en die werklike straf, die crux. Selfs die noem van laasgenoemde is ondraaglik vir 'n Romeinse burger. Kruisiging was 'n godsdienstig-politieke straf, met die klem op die politieke sy daarvan. Dit was die straf vir rebelse vreemdelinge, gewelddadige kriminele en rowers. Kruisiging was ook 'n manier om oorlog te verhoed, rebelle en rebelse stede of provinsies te beheer. Dit was dus 'n maatreël om vrede te verseker asook die manier waarop 'n regeerder gesorg het dat hy in beheer bly. Daar is nie onderskeid getref tussen die gesag van die millitêre mag, die polisie en die mag van die regswêreld nie. Enigeen van dié magte kon dus die straf voltrek. Oor die algemeen was die landelike bevolking baie dankbaar as rowers tereggestel is. Kruisiging is gesien as ' $n$ instrument om die bevolking te beskerm teen kriminele en geweldenaars, maar dit het ook as 'n afskrikmiddel gedien vir ander oortreders. 
Volgens Hengel (1977:51) is kruisiging deur die meeste Romeinse skrywers gesien as die tipiese straf vir slawe. Hy wys ook daarop dat die term, servile supplicium, slawestraf, deur onder andere Valerius Maximus, Tiberius en Tacitus gebruik word om van kruisiging te praat. Hengel verwys na Plautus wat skryf van die slaaf, Crysalus ('gouddraer') wat sy eienaar bedrieg het en bang was, dat hy (eienaar) sy (slaaf) naam sal verander na Crucisalus ('kruisdraer'). Dit dui op die gebruik dat 'n terreggestelde die dwarsbalk van sy eie kruis, na die plek van kruisiging moes dra (kyk egter Van der Watt \& Joubert 1996 vir die vraag of dit slegs die dwarsbalk of die hele kruis was). Ford (1995) sê dat daar 'n ou Romeinse wet was waarvolgens al die slawe van 'n huishouding gekruisig is as een van hulle hulle eienaar vermoor het. Dit het gebeur wanneer hulle deel gehad het aan die beplanning van die moord. Op hierdie manier het die eienaar verseker dat hy veilig is, omdat hulle moontlik 'n bedreiging vir sy lewe kon wees. Ford verwys dan ook na die geval wat deur Tacitus (Ann 14.43) aangeteken is. Tacitus skryf oor die kruisiging van Pedanius Secundus se hele huishouding wat vier honderd slawe ingesluit het, nadat hy deur sy slaaf vermoor is.

'n Slaaf het dus baie min, indien enige, beskerming gehad teen sy/haar eienaar. Aangesien 'n slaaf gesien is as deel van die heer se eiendom, kon hy met sy slaaf doen net wat hy wou. Dit blyk duidelik uit die dialoog tussen 'n Romeinse eredame en haar man, wat Hengel (1977:58) uit Controversiae aanhaal: Pone crucem servo! - Meruit quo crimene servus supplicium? quis testis adest? quis detulit? audi; nulla umquam de morte hominis cunctatio longa est. - $O$ demens, ita servus homo est? nil fecerit esto; Hoc volo, sic iubeo, sit pro ratione voluntas! 5

Uit bogenoemde gegewens blyk dit duidelik dat ten spyte van die feit dat kruisiging vir die Romeine ' $n$ wrede vorm van teregstelling was, dit steeds uitgevoer is. Dit is veral toegepas op slawe en meestal in geval van dislojaliteit teenoor hulle eienaars, hoewel Romeinse burgers nie altyd oor die hoof gesien is nie. Ook hulle is gekruisig wanneer hulle skuldig was aan oortredings soos hoogverraad, spioenasie, rebellie teen die staat en drostery of oorloop na die vyand. Hierdie straf is gebruik om opstand te onderdruk en vrede te handhaaf.

\section{KRUISIGING ONDER DIE GRIEKE}

Tot dusver is die Griekssprekende wêreld, Griekeland, Klein-Asïë, Egipte en Sirië, buite bespreking gelaat. Alhoewel die meeste bronne in verband met kruisiging in Latyn is, is dit geen bewys vir die Grieke se onskuld in hierdie verband nie. Hengel (1977:69) wys daarop dat dit foutief sal wees om 'n onderskeid te maak tussen die Latynse 'Weste' en die Griekse 'Ooste' of selfs tussen die Persiese 'Ooste' en die Griekse 'Weste'. Die omstandighede rondom Pheretime, die moeder van die vermoorde Arcesilaus, die tiran van Barca in Cyrenaica, bevestig Hengel se oortuiging. 
Pheretime het diegene wat betrokke was by haar seun se dood, buite die stadsmuur laat kruisig. Pheretime was net so Grieks as haar slagoffers (kyk Hengel 1977:69; Herodotes 4.202,1).

'n Ander voorbeeld van kruisiging onder die Grieke, is dié van die byvroue van Agathocles. Ford (1995) verwys na Justinus se Epitoma Historiarum Philippicarum in die verband. Die konteks waarteen dit afspeel, was die vyandskap tussen Antiochus, koning van Sirië, en Ptolemeus, koning van Egipte. Ptolemeus het Atiochus geopponeer, maar hy was tevrede om die oorwonne stede te herstel. Dit het daartoe gelei dat hy betrokke geraak het by die losbandige lewe van die minnaresse van Agathocles. Hy (Agathocles) het beheer oor die staat gekry, en niemand was magtiger as die koning self nie. Toe die gebeure bekend geword het, is Agathocles doodgemaak, en uit wraak vir die dood van Euridice, het die koning se vrou die byvroue laat kruisig. Hengel (1977:71) wys ook daarop dat Creon in Sophocles se Antigone nie net gedreig het om diegene wat bekend is met die begrafnis van Polinisus, dood te maak as hulle nie praat nie, maar om hulle lewendig op te hang. Hy sê ook dat slawe volgens Cratinus (in sy Thesmophoriazusai) gereeld gekruisig is en dat Plato en Demosthenes bekend was met hierdie vorm van teregstelling. Ford (1995:13) haal ook aan uit Diodorus van Siculus se geskrifte. In sy tweede boek skryf hy oor die gebeure in Asië, in die tyd van die Assiriërs. Hy beskryf hoe Ninus, die koning van die Assiriërs, vir Pharnus, die koning van Media, verslaan het. Hy het die koning (Pharnus), sy sewe seuns en sy vrou gevange geneem, en hulle laat kruisig6.

In dieselfde boek skryf Diodorus oor die lewe van Semiramis, die vrou van koning Ninus. Sy was 'n baie dinamiese vrou en na haar man se dood het sy die troon bestyg. Volgens Diodorus het sy Babilonië gestig, die hangende tuine gemaak en opgeruk teen Egipte, Ethiopië en Indië. Deidorus maak melding van 'n brief wat die koning van Indië, Stabrobates, aan haar geskryf het en waarin hy haar uitkryt vir 'n aggresor en 'n slet. Hy roep die gode as getuies dat hy haar sal kruisig wanneer hy haar oorwin het (Diodorus 2:18,1). Ford is van mening dat Semiramis so gedreig word omdat sy in die samelewing se oë skandalig opgetree het deur die rol van 'n man te vertolk, veral in oorlog en leierskap. Sy het die militêre voorregte van 'n man vir haarself toegedien. Ford (1995) verwys ook na die agtiende boek van Diodorus van Siculus waarin hy die versteurings in die weermagte, na die dood van Alexander, beskryf asook hoe Perdiccas aan bewind gekom het. Perdiccas het koning Ariarathes verslaan, hom en sy ondersteuners gevange geneem, hulle gemartel en opgehang/deurboor ${ }^{7}$. Ook Hengel (1977:73) verwys na die gebeurtenis.

Hengel (1977:74) vermeld verder die kruisigings wat onder die bewind van Antiochus III plàasgevind het en dat Josephus, in sy Antiquitates, berig van wetsgehoorsames in Judea wat gekruisig is tydens die bewind van Antiochus IV in 167 v C. Hy sê 
ook dat selfs in die pre-Romeinse, Hellenistiese periode, knisiging bekend was as ' $n$ straf vir staatskriminele, ook in die Griekssprekende Ooste. Hy wys daarop dat Plutarchus bewus was dat elke oortreder, wat ter dood veroordeel is, sy kruis op sy rug moes $\mathrm{dra}^{8}$ (Hengel 1977:77 - Moralia 554A).

In die Griekssprekende wêreld was kruisiging net so bekend as in die ander gebiede. Die straf is ook deur die gemeenskap voltrek. Hengel verwys in hierdie verband na onder andere Amysos van Caria wat berig dat dit die stadsburgers was wat die slaaf, wat sy eienaar vermoor het, opgehang het, sodat die wilde diere hom kon opvreet (Hengel 1977:76; Marshall 1916). In teenstelling met die Romeine was dit dus nie net die owerhede wat die kruisigingspraktyk toegepas het nie, maar ook die gewone burgers. In die Griekse gemeenskap was daar ook nie so 'n streng klasseonderskeid met betrekking tot wie gekruisig is en wie nie. Die redes vir kruisiging is orals dieselfde. Die Grieke het ook die doodstraf opgelê ( $\mathrm{d} \mathrm{m} \mathbf{v}$ kruisiging) vir oortreders soos diegene wat skuldig was aan hoogverraad, oorlog georiënteerde optredes, rebelse slawe, opstokers en moord. Ook hier is kruisiging gebruik om onrus te onderdruk en vrede te handhaaf. Dit het ook die gewone burgers beskerm teen die wandade van kriminele.

\section{KRUISIGING ONDER DIE ISRAELIETE}

Of die Israeliete gekruisig het, is 'n veel gedebatteerde saak. Dat Israeliete gekruisig is, is ' $n$ aanvaarde feit. Hengel (1977:85) verwys veral in die verband na die Talmudiese materiaal: 'we have a whole series of references to the crucifixion of Jews during the later empire'.

In I Korinthiërs 1:23 en Galasiërs 5:11 word gesê dat die kruis 'n skande was in die Israeliete se oë. Die oortuiging het 'n religieuse agtergrond wat teruggevoer kan word na Deuteronomium 21:22, 23: 'Wanneer iemand tereggestel word as gevolg van 'n oortreding wat die doodstraf verdien, en jy hang hom aan 'n paal op, mag sy lyk nie die nag daaraan bly hang nie. Jy moet hom dieselfde dag nog begrawe, want wie opgehang word, is deur God vervloek. Jy mag nie die land wat deur die Here jou God aan jou as besitting gegee is, verontreinig nie' (NAV). (Kyk die volgende afdeling vir 'n bespreking van die verskillende interpretasies van dié gedeelte.)

Volgens Sanh VII.1 was die vorms waarvolgens teregstelling onder die na-eksiliese Israeliete plaasgevind het: steniging, verbranding, onthoofding en verwurging. Dit is hierdie gedeelte wat daartoe bydra dat die idee bestaan dat kruisiging nie ' $n$ Israelitiese straf was nie. Hierdie vorm van teregstelling word gewoonlik gereken as 'n heidense gebruik. Dit het die idee laat ontstaan dat die oorsprong van kruisiging aan die Romeine te danke is en dat dit slegs deur Romeinse owerhede uitgevoer is. Bammel (1970) wys daarop dat dit nie die enigste vorm van teregstelling in die Joodse gemeenskap was nie en dat dit inderdaad onwaar sou wees om te beweer dat bogenoemde 
metodes die enigste was wat toegepas is. Hy verwys onder andere na die Targum op Rut 1:17, wat melding daarvan maak dat steniging, verbranding, onthoofding en hang die vorms van teregstelling was. Hy vestig ook die aandag op Sanh VII.3 wat sê dat onthoofding deur die swaard, 'soos wat die regering maak', ook 'n aanvaarbare metode (ook erken deur die Mishnah) is. Die invloed van die Romeinse gebruik om iemand met 'n stok te slaan, kan ook gesien word in Makkoth III.12 wat verwys na voorskrifte met betrekking tot om iemand met rieme te slaan. Hierdeur wil dit blyk of die Jode nie so streng gehou het by alle voorskrifte nie en dat hulle ook beïnvloed is deur die sosiale juridiese 'teks'.

Bammel (1970:78) beweer dat dit nie onmoontlik is dat die na-eksiliese Israeliete wel kruisiging gebruik het nie: 'the practice of this form of execution was not an alien possibility even to Jewish judges. It seems that the punishment was only clearly characterised as Roman in the course of this process and in this way was disqualified'. Bammel verwys ook na Stauffer (1957) wat beweer dat kruisiging in Israel toegepas is sedert die tweede eeu $v \mathrm{C}$ en dat dit veral in geval van politieke oortredings plaasgevind het, aangesien dit ' $n$ baie wrede vorm van straf was.

In teenstelling met Bammel beweer Rosenblatt (1956) dat kruisiging volgens die Farisese wet ontoelaatbaar was. Hy wys op die reeds genoemde argument dat dit nie een van die voorskrifte vir teregstelling was nie. Hy gee wel toe dat persone wat skuldig was aan doodstraf, 'such as the blasphemer and idolter ... were impaled' (Rosenblatt 1956:318). Tzaferis (1985) sê dat kruisiging 'n $\dot{\alpha} \nu \alpha \dot{\theta} \varepsilon \mu \alpha$ vir die Israeliete was, maar dat dit wel deur Judese tiranne in die Hasmoniese tydperk toegepas is. Hy verwys ook na die massakruisiging van agt honderd Fariseërs op een dag deur die hoëpriester Alexander Jannaeus tydens die opstand teen die sensus van $7 \mathrm{n} \mathrm{C}$, soos opgeteken deur Josephus in sy Antiquitates 13 (vgl ook Hengel 1977; Feldman \& Hata 1987). Hengel (1977:84) en Ford (1995) verwys ook na die keer toe rabbi Simeon b Shetah sewentig of tagtig hekse in Askelon laat hang het. Dit is egter nie duidelik dat dit 'n geval was van 'hang om te sterf' of 'hang nadat gesterf het' nie. Volgens die aanhaling wat Ford (1995) uit Sanh 43b gee, was die gebruik om 'n lyk op te hang na teregstelling nie 'n vreemde verskynsel vir die Israeliete nie.

Uit die gegewe inligting is dit duidelik waarom daar steeds gedebatteer word oor kruisiging deur Israeliete. Daar is wel bewyse van sulke gebeurtenisse, maar hoe algemeen dit voorgekom het en of dit aanvaarbaar was vir die Israeliete, is nie so duidelik nie. In die volgende gedeelte gaan daar gekyk word na die Qumran-teks wat volgens Yadin (1985) lig werp op die saak. Die teks sal eers vertaal en bespreek word waarna daar ' $n$ bespreking sal volg van die moontlike interpretasies. 
6. $11 \mathrm{Q}$ TEMPEL $64.6-13$

\subsection{Teks}

כ... 6

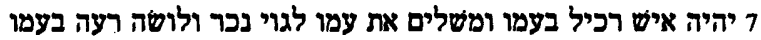

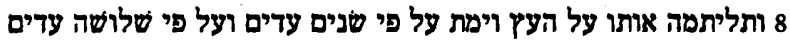

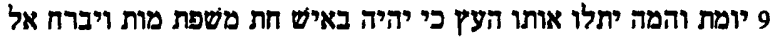

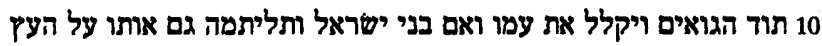

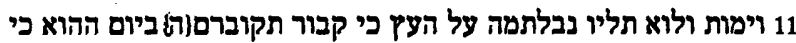

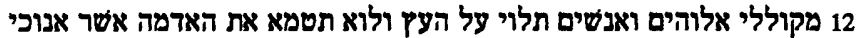

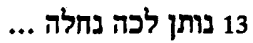

\subsection{Vertaling}

YADIN

6.1f.7. a man informs against his people, and delivers his people up to a foreign nation, and does harm to his people, 8. you shall hang him on the tree and he shall die. On the evidence of two witnesses and on the evidence of three witnesses 9. he shall be put to death, and they shall hang him on the tree. And if a man has committed a crime puni-

\section{BAUMGARTEN}

6.If 7. a man has informed against his people and has delivered his people up to a foreign nation and has done evil to his people. 8. you shall hang him on the tree and he shall die. On the evidence of two witnesses and on the evidence of three witnesses 9. he shall be put to death, and they shall hang him on the tree. If a man has committed a crime punishable

\section{MAIER}

6. If 7. a man passes on information about his people and betrays his people to a foreign people and does evil to his people, 8. then you shall hang him on the wood, so that he dies. On the strength of two witnesses or on the strength of three witnesses 9 . he shall be killed and they shall hang him on the wood. If a man has committed a capital offence and flees
EIE

6. As 7. 'n man/ iemand sy volk beskinder en sy volk oorlewer aan 'n vreemde volk en (iets) slegs doen aan sy volk 8. sal/moet julle hom op die stok hang en hy sal doodgaan. Op die getuienis (mond) van twee en op die getuienis van drie 9. sal hy dood gemaak word en hulle sal hom ophang op die stok. As 'n man 'n cortreding (begaan) wat straf 
shable by death, by death and has and has defect into run away to 10 . 10. the midst of the midst of the the nations, and Gentiles and has has cursed his cursed his people people and the and the children of children of Israel, Israel, you shall you shall hang him hang him also on aslo on the tree, the tree 11. and he 11. and he shall shall die; and you die. And their bo- shall not leave dy shall not re- their bodies upon main upon the tree all night, but you shall bury them the same day, for 12. those hanged on the tree are accursed by God and men; you shall not defile the land which I 13. give you for an inheritance ... the tree in the night but you shall bury them the same day, for 12 . the hanged upon the tree are cursed by God and men; and you shall not defile the land which I 13. give you as an inheritance ... to 10. the nations baar is met die and curse his dood en wegloop peole, the 10. na die idole Israelites, then you van die vreemde shall also hang volke en sy volk him on the wood, en die kinders van 11. so that he dies. Israel vervloek, Yet they shall not sal julle hom ook let his corpse hang hang op die stok, on the wood, but 11 . sodat hy sal must bury it on the doodgaan. Maar same day, for 12 . julle moenie die cursed by God and gehangdes aan die men are those who boom los nie, are hanged on the maar hulle bewood and you grawe op dieselfde shall not pollute dag, want 12. die the earth, which I wat aan die stok 13. give you as an hang is vervloek inheritance ... deur God en mense; sodat julle nie die grond, wat ek 13. as erfenis gee, sal verontreinig/ besmet nie ...

\subsection{Bespreking}

ry - Hierdie woord word gewoonlik gebruik om van 'n boom te praat, maar dit kan ook hout, stok, paal of galg beteken (kyk Deut 21:22-23; Gen 40:19; Ester 2:23). Hierdie stok of paal kan 'n gewone regop paal wees waaraan iemand opgehang is (kyk Van der Watt \& Joubert 1996). Dit kan egter ook 'n skerpgemaakte vertikale stok

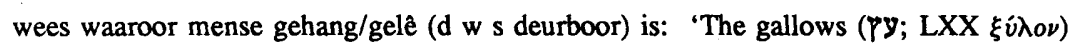
is described in the Mishna as a gibbet; the dead man's hands were tied together and slung over the arm. Since impaling was practiced in Persia (Herodotes III. 125, 159),

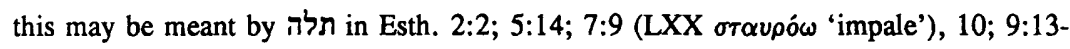
14' (Buttrick 1962:525). Dit was nie vreemd om enige van hierdie voorwerpe te 
gebruik nie. Daar is op beide maniere gekruisig. Albei vertalings van py is dus aanvaarbaar.

ת - Hierdie is die Hebreeuse vorm van die Aramese slb. Dit word gewoonlik vertaal met ophang of hang. Dit kon egter ook 'deurboring' beteken (kyk bg bespreking). Baumgarten (1972) betwyfel dit of 'hang aan 'n hout' dieselfde is as 'om te kruisig'. Hy beskou dit as een van die vier tradisionele vorms van teregstelling, en dan spesifiek as 'n manier van (versmoring/strangulation). Yadin (1983) beskou die verskil tussen hang en kruisig as relatief onbelangrik. Hy beklemtoon die dubbele herhaling van 'en julle sal hom hang' wat gevolg word deur 'en hy sal doodgaan'. Hier word die normale volgorde van Deut 21:22, 23 omgekeer. Dit dui duidelik daarop dat die Qumran-gemeenskap dit geïnterpreteer het dat iemand opgehang moet word en dat doodgaan die gevolg daarvan was. Dit is in teenstelling met die Farisese halakha, waarvolgens iemand doodgemaak is voordat hy/sy.opgehang is.

\subsection{Inhoud}

Inhoudelik kan die teks in twee gedeeltes verdeel word. Die eerste gedeelte (reël 6-10) verskaf die redes vir kruisiging of teregstelling. Op hierdie punt is dit duidelik dat die 'sosiale teks' 'n sterk invloed uitgeoefen het. Dieselfde redes waarom die ander naburige volke mense laat kruisig het, is ook hier ter sprake. Net soos die Romeine 'n uitsondering gemaak het in geval van hoogverraad (selfs Romeinse burgers is gekruisig), het die Judese sekte (Esseners) ook hoogverraad beskou as 'n ernstige oortreding wat met die gruweldood van kruisiging strafbaar was.

Die tweede gedeelte van die teks behandel Deuteronomium 21:22-23. In teenstelling met die gangbare interpretasie onder die ander Jode het die Qumran-gemeenskap dit anders geïnterpreteer. Hulle interpretasie het dit moontlik gemaak om kruisiging as 'n vorm van teregstelling te implementeer. Deuteronomium 21:22-23 is, soos reeds genoem, die teks wat die meeste gebruik word om die Israeliete se onskuld met betrekking tot kruisiging aan te toon. In 11QTempel 64.11-13 word daar ook verwys na hierdie Deuteronomiumteks; die interpretasie daarvan verskil egter. Bernstein (1983) wys op die verskillende interpretasiemoontlikhede van Deuteronomium 21:22-23. Hy sê dat קלל אלוהימ as 'n subjektiewe ('n vloek van God) of objektiewe genitief ('n vloek vir God) verstaan kan word.

Die Septuagint is die oudste bron wat die subjektiewe genitief gebruik ('vervloek deur [v้ $\pi 0$ ] God is elkeen wat aan 'n boom gehang is'). Alhoewel Paulus nie die verse aangehaal het in Galasiërs 3:13 nie, is dit duidelik dat ook hy dit subjektief verstaan het. Die een 'normatiewe' na-eksiliese Israelitiese bron wat die subjektiewe genitief 
gebruik het, is die Targum Neofiti. Bogenoemde bronne deel met mekaar die verande-

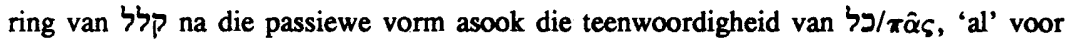
'gehang'. Wanneer daar gekyk word na die gebruik van die objektiewe genitief, is dit meer ingewikkeld, aangesien daar ten minste twee verstaansmoontlikhede vir die objektiewe genitief is. $\mathbf{R}$ Eliezer en die sofiste, asook Josephus, beskou 'vloek van God' dieselfde as ' $n$ vloeker van God'. Daar is egter 'n probleem met hierdie interpretasie. Eerstens, hoe is dit moontlik om van 'vloek van God' af uit te kom by 'vloeker (blasphemer) van God'? Tweedens, hierdie teks dien 'n spesifieke doel, naamlik om 'n rede te gee om die lyk van die kruis/boom te verwyder, terwyl dit in hierdie geval die rede vir die teregstelling verskaf.

R Meir gaan ook uit van die objektiewe genitief, maar begrond 'die vloek van God' op die feit dat die mens ' $n$ beeld van God is. Wanneer 'n mens, wat die beeld van God is, gehang word, is dit 'n vernedering en belediging vir die mens en ipso facto ook vir God. Rashi gee die klassieke interpretasie van die Mishnah, deur die klem te verskuif na die verbygangers se kommentaar. In dié geval gebruik hy dieselfde tipe interpretasie as $\mathrm{R}$ Meir. Hy verskil egter daarin dat die verbygangers volgens hom die rede gee waarom die lyk verwyder moet word, want net die feit dat die mens ontbloot is aan die kruis, is ' $n$ belediging van God, aangesien die verbygangers kommentaar lewer oor die beeld van God. Betz (1988) verwys na Johannes 19:7, waarin die opmerking van die Judese tempelowerhede aan Pilatus voorkom dat hulle 'n wet het en volgens daardie wet moet Christus gekruisig word, omdat Hy Hom skuldig gemaak het aan Godslastering deur te sê dat Hy die Seun van God is. Betz beweer dat hier na Deuteronomium 21:22-23 verwys word soos wat dit verstaan is in die Esseense gemeenskap.

Yadin (1983) meen dat קלל קלוהימ in die Qumranteks eers objektief (reël $10-$ 'vervloek sy volk') en dan subjektief (reël 11-12 - 'vervloek deur God en mens') gebruik word. Bernstein (1983) wys egter daarop dat die 'dubbele eksegese' twyfelagtig is. Hy sê dat die Tempelrol hierdie reël verstaan as 'n subjektiewe genitief, en dat enige ooreenkoms tussen reël 10 en die gedeelte in Deuteronomium, wat moontlik kan dui op 'n objektiewe verstaan, op die meeste 'n stilistiese ooreenkoms kan wees. Volgens Bernstein het die subjektiewe genitief nooit heeltemal verdwyn uit die Israeliete se verstaan van Deuteronomium 21:22-23 nie. Die Israeliete sowel as die skrifgeleerdes van daardie tyd was bewus van die verskillende interpretasiemoontlikhede en het dit ook soms ironies gebruik. Hy wys verder darop dat al die verskillende verstaansmodelle op dieselfde kriterium berus, naamlik om ' $n$ rede te verskaf waarom die lyk van die kruis verwyder moes word. 


\subsection{QpNahum in die lig van 11QTempel 64. 6-13}

In hierdie kommentaar op Nahum is daar ' $n$ teks wat dui op dieselfde vorm van teregstelling. Aangesien dit ' $n$ baie fragmentariese teks is, het dit al verskeie kontroversiële standpunte by geleerdes uitgelok. Die teksgedeelte waaroor Yadin (1985) en Baumgarten (1972) verskil, lyk soos volg: '.. Its hidden interpretation concerns the Lion of Wrath $[\ldots]$ death unto the seekers of smooth things and who hangs men alive $[\ldots]$ in Israel as of old since the hanged one is called ...' (soos aangehaal en vertaal deur Yadin 1985).

Yadin konstrueer die gedeelte wat volg op 'and who hangs men alive', op grond van 11QTempel 64, soos volg: 'as is the law'. Die gedeelte lees dan soos volg: 'and who hangs men alive, as is the law in Israel of old'. Geleerdes wat Yadin se standpunt ondersteun, is onder andere Martin Hengel en Joseph A Fitzmyer, beide geleerdes wat goed onderlê is in die vakgebied. Diegene wat dit nie aanvaar nie, is onder andere A Dupont-Sommer, Amusin en Baumgarten. Baumgarten (1972) daarenteen konstrueer dit soos wat dit in al die tye vóor die ontdekking van die Tempelrol gedoen is: 'who hangs men alive on the tree which was not done in Israel as of old.' Alhoewel Yadin se konstruksie grammatikaal meer aanvaarbaar is, is daar nóg vir sy konstruksie nóg vir dié van Baumgarten enige oortuigende argumente.

\section{KONKLUSIE}

In die inleiding is die volgende twee vrae gevra: (1) Is die sosiale teks die 'interteks' vir 11QTempel 64.6-13? (2) Kon ander na-eksiliese Israeliete ook beïnvloed word deur die sosiale teks? Uit die inleiding van hierdie studie het dit duidelik geword dat die term intertekstualiteit verwys na die gebruik in die literêre wêreld om op ander tekste te steun, sodat elke diskoers in dialoog is met die voorafgaande diskoerse oor dieselfde onderwerp (Viljoen 1993:314); in so 'n mate dat 'n teks gesien kan word as die absorbering en antwoord op 'n ander teks (Gräbe 1996:3). Wanneer daar in ag geneem word dat teks ook gebeurde teks is en daar word gelet op die resultate van hierdie studie, blyk dit moontlik te wees dat die sosiale kruisigingsteks(te) die interteks vir 11QTempel 64.6-13 kon wees.

Uit die gegewe ondersoek is dit duidelik dat die Qumran-gemeenskap dieselfde oortredinge met kruisiging gestraf het. Ook die manier waarop kruisiging uitgevoer is, stem ooreen met dié van die sosiale teks. Dit blyk dat die gemeenskap selfs 'n ander interpretasie aan Deuteronomium 21:22-23 gegee het, sodat hulle kruisiging as straf kon implementeer. Die herhaling van dieselfde gedagtes as dié van die sosiale teks, asook die invloed wat die sosiale teks op 11QTempel 64.6-13 kon gehad het, maak dit dus moontlik dat die sosiale teks die interteks kon wees vir 11QTempel 64.6-13. 'n Mens kan selfs sover gaan om te sê dat die sosiale teks die oorsaak was vir die ontstaan van 11QTempel 64.6-13. 
Uit die ondersoek het dit (veral uit Bammel 1970 se artikel) duidelik geword dat die Israeliete nie so rigied by hulle voorskrifte vir teregstelling gebly het nie. Wanneer dit in ag geneem word, sowel as die feit dat die Qumran-gemeenskap 'n afgeslote gemeenskap was wat as 't ware 'n kloosterbestaan gevoer het, is dit moeilik om 'n negatiewe antwoord op die tweede vraag te gee. As die anti-sosiale Esseners deur die sosiale teks beïnvloed kon word, hoeveel te meer nie ook die ander Joodse gemeenskappe nie?

\section{Endnotas}

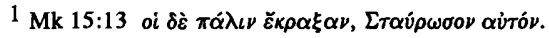

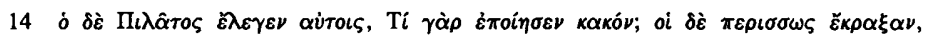

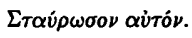

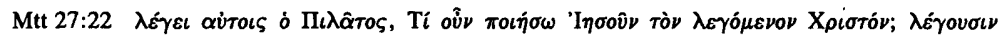
$\pi \dot{\nu} \nu \tau \varepsilon, \Sigma \tau \tau \alpha \nu \rho \omega \dot{\tau} \tau \omega$.

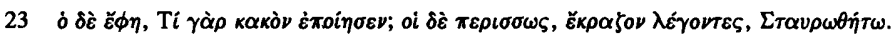

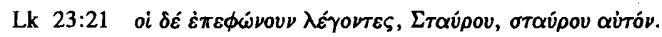

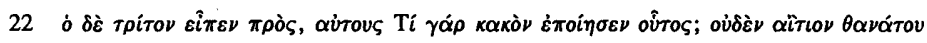

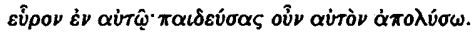

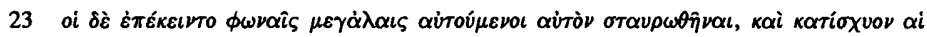

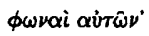

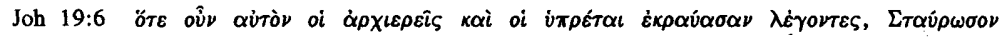

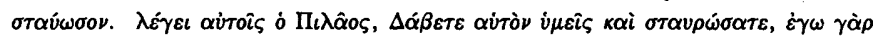

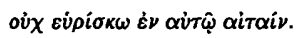

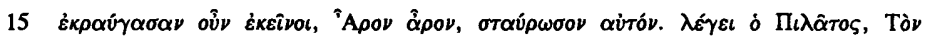

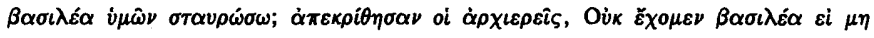

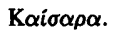

2 Deut 21

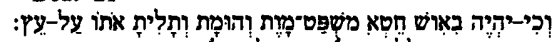

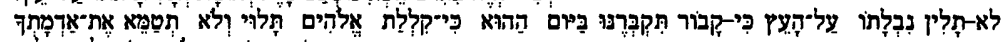

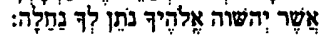

3

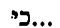

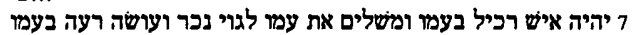

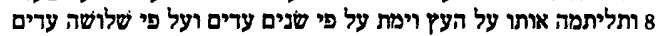

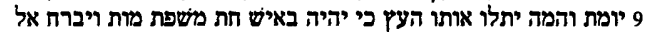

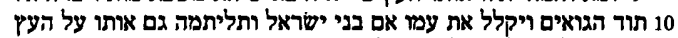

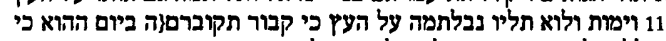

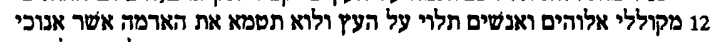
13 נותן לכה נחלה .... 
4 'Ek sien daar kruise, nie slegs een soort nie, maar op verskillende wyses gemaak: sommige het hulle slagoffers met hulle hoofde na onder (opgehang), sommig se geslagsdele is deurboor, ander met hulle arms uitgestrek aan die galg'.

5 Vrou: 'Kruisig die slaaf!'

Man : 'Watter oortreding wat die dood verdien, het hy begaan? Waar is die getuies teen hom? Wie berig teen hom? Luister (ten minste) na hom; geen uitstel kan te lank wees as ' $n$ mens se lewe op die spel is nie'.

Vrou: ' $O$, jou idioot, noem jy 'n slaaf 'n mens? Se jy dat hy onskuldig is? Hierdie is my wil en my bevel. Neem dit as 'n bewys vir die daad!'

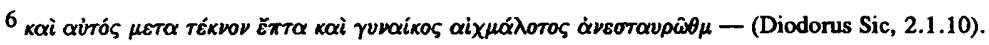

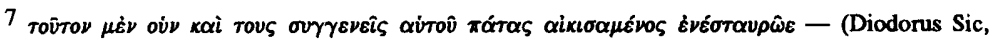
18.16).

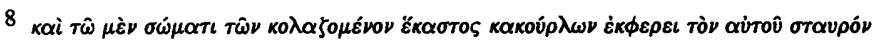

* By die תऽש's in reël 9 staan daar 'n $\mathrm{x}$ bo-kant die lyn.

** Die $\mathrm{N}$ in reël 10 is 'n 1 laer gedruk.

\section{Literatuurverwysings}

Allegro, J M 1979. The Dead Sea scrolls and the Christian myth. Newton Abbot: Westbridge Books.

Bakhtin, M M 1981. The dialogic imagination, edited by Holquest, $\mathbf{M}$ and tr by Ermerson, C \& Holquest, M. Austin: University of Texas Press.

Bammel, E 1970. Crucifixion as a punishment in Palestine: The trial of Jesus. London: SCM Press.

Barthes, R 1953. De nulgraad van het schrijven gevolgd door inleiding in de semiologie. Amsterdam: Meulenhoff.

1988. The semiotic challenge. Oxford: Basil Blackwell.

Baumgarten, J N 1972. Does 'tlh' in the Temple Scroll refer to crucifixion. JBL 91, $742-481$.

Bernstein, N J 1983. Ky qllt 'lhym tlwy (Dt 21:23): A study in early Jewish exegesis [11QTemple 64:6-13]. Jewish Quarterly Review 74/1, 21-45.

Betz, O 1988. The Temple Scroll and the trial of Jesus. Southwestern Journal of Theology 30/3/111, 5-8. 
Betz, O 1992. Jesus and the Temple Scroll, in Charlesworth, J H (ed), Jesus and the Dead Sea Scrolls. New York: Doubleday Dell Publishing Group.

Buttrick, G A 1962. The Interpreter's Dictionary of the Bible, Vol 2. Nashville: Abingdon Press.

Claes, P 1987. Bijzondere en algemene intertextualiteitstheorie. Spiegel der Letteren 20/1-2, 7-15.

Cloete, T T 1992. Literêre terme en teorieè. Pretoria: Haum-literêr.

Crossan, J D 1995. Who killed Jesus? New York: HarperCollins.

Denthith, S 1995. Bakthinian thought. New York: Routledge.

Feldman, L H \& Hata, G (eds) 1987. Josephus, Judiasm, and Christianity. Detroit: Wayne State University Press.

1989. Josephus, the Bible, and history. Detroit: Wayne State University Press.

Ford, J M 1976. 'Crucify Him, Crucify Him', and the Temple Scroll. Expository Times 87, 275-278.

1995. The crucifixion of woman in antiquity. Voordrag gelewer voor die Context Group. A project on the Bible in its Cultural Environment. Portland, Ore-gon, Maart 1995.

Foster, P H 1993. Die roman as meertalige lag: Die diskoers in Wilma Stóckenström se Abjater wat so lag. Tydskrif vir Literatuurwetenskap 9, 326-328.

Funk, R W 1990. New Gospel parallels, 1, 2. California: Polebridge Press.

Gräbe, I 1996. Bybelse spieserye? Intertekstuele stemmespel in Jan Spies se volksvertellings. Voordrag gelewer tydens NTWSA-jaarkongres, Universiteit van Pretoria, April 1996.

Halperin, D J 1981. Crucifixion, the Nahum Pesher, and the rabbinic penalty of stangulation. Journal of Jewish Studies 32, 32-46.

Hengel, M 1977. Crucifixion. London: SCM Press.

Jastrow, M (comp.) 1992. A dictionary of the Targumim, the Talmud Babli and Yerushalmi, and the Midrashic Literature. New York: The Judaica Press.

Kristeva, J 1980. Word dialogue and novel: 'Desire in language'. A Semiotic approach to literature and art. Oxford: Basil Blackwell.

1984. Revolution in poetic language. New York: Columbia University Press.

Lernout, G 1987. Intertextualiteit als programma. Spiegel der Letteren 20/1-2, 33-42.

Maier, J 1985. The Temple Scroll. Sheffield: The University of Sheffield Press.

Miller, R J (ed) 1992. The complete gospels. California: Polebridge Press.

Morson, G S 1981. Bakhtin: Essays and dialogues on his work. London: The University of Chicago Press. 
Neusner, J 1987. Josephus' Pharisees: A complete repertoire in Feldman \& Hata (eds), Josephus, Judaism, and Christianity. Detroit: Wayne State University Press.

Rosenblatt, S 1956. Crucifixion of Jesus from the standpoint of Pharasaic law. JBL $75,315-321$.

Sivan, R \& Levenstein, E 1975. The New Bantam-Megiddo Hebrew \& English Dictionary. New York: Bantam Books.

Tzaferis, V 1985. Crucifixion: The archeological evidence - remains of a Jewish victim of crucifixion found in Jenusalem. Biblical Archeology Review 11/1, 44-53.

Van der Watt, J G \& Joubert, S J 1996. Hoe is Jesus gekruisig? HTS 52/4, 633-652.

Van Gorp, $H$ et al 1990. Lexicon van Literaire Termen. Wolters - Noordhoff.

Van Peer, W 1987. Intertextualiteit: Traditie en kritiek. Spiegel der Letteren 20/1-2, 16-24.

Viljoen, L 1993. Die roman as polifonịe: Diskursiewe verskeidenheid in Lettie Viljoen se 'Belemmering'. Tydskrif vir Literatuurwetenskap 9, 313-325.

Yadin, Y 1983. The Temple Scroll, Volume II: Text and Commentary. Jerusalem: 'Ahva' Coopertive Press.

1985. The Temple Scroll: The hidden law of the Dead Sea Sect. London: Weideneld \& Nicolson, London. 